\title{
SHAKESPEARE GÜNLERİ
}

\author{
(20 - 22 NISAN 1992)
}




\section{Nisan 1992, Pazartesi}

10.00 Prof. Dr. Sevinç Sokullu

"Elizabeth Dönemi Oyun Mekanları ve Globe"

11.00 Prof. Dr. Bülent R. Bozkurt

"IV. Henry Oyunuida Politika, Komsdi ve

Insainlik Komedyası"

14.00 Doç. Dr. Ayşegül Yüksel

"Troilus ve Cressida: Sorunlu bir Soruin Oyunu"

15.00 Dr. Hamit Galışkan

"Macbeth: Kralı Öldürmek"

16.00 . Shakespeare Oyunlarındain Şarkılar

Dersin .Sorumlusu: Öğx. Gör. Nedim Yuldux

Elizabeth Dönemi Danslarrndai Bir Örnek

Dersin .Sorumlusu: Uzm. Yasemin Kalaç

17.00 Oyun: Bir Yazdönümü Gecesi Rüyası

Yöneten: Öğr. Gör. tpek Çalışkur

\section{Nisan 1992, Salr}

$10.00^{\circ}$ Prof. Dr. Ünal Aytür

"Shakespeare ve Cinsellik".

11.00 Prof. Dr. Cevat Gapan

"Musiki Aşkı Besliyorsa Eğer"

14.00 Doç. Dr. Fatma Necla Çıkigil

"Shakespeare"de Coşku"

15.00 Shakespeare Oyunlarıindan Şarkılar

Dersin Sorumlusu: Öğr. Gör. Nedim Yilduz

Elizabeth Dönemi Danslarindan Bir Örnek

Dersiin Sorumlusu: Uzm. Yasemin. Kalaç

16.00 "Hırģn Kız'dan Bir Sahne: Sekiz Ayr Biçem Deizemesi"

Dersin Sorumlusu: Öğr. Gör. Ergin Orbey

22 Nisan 1992, Çarģamba

10.00 Prof. Dr. Engin Uzmen

"Bir Yazdönümü Gecesi Rüyası"

11.00 Doç. Dr. Ünal Norman

"Shakespeare Oyunlarinda Hareket Yapimı"

14.00 Soj Sinif Seminer Cralı̧ması: "Shakespearc'in

Oyunlarında Doğa və Doğaüstü Güçler"

Dersin Sorumlusu: Yrd. Doç. Dr. Selda Önduil

15.00 Oyun: Bir Yazdönümü Gecesi Rüyas

Yöneten: Öğr. Gör. Ipek Çalı̧̧ur 